\title{
TWENTY-FIRST CENTURY BANISHMENT: CITIZENSHIP STRIPPING IN COMMON LAW NATIONS
}

\author{
Sangeetha Pillai* and George Williams**
}

\begin{abstract}
Three common law countries - the UK, Canada and Australiahave significantly expanded citizenship revocation laws as a counterterrorism response. This article provides a detailed examination of these laws, their development and their use. It also explores and critiques the extent to which the laws shift citizenship away from fundamental common law principles, and the means by which such a shift has been justified.
\end{abstract}

Keywords: citizenship, common law, comparative law, counterterrorism, human rights, public law.

\section{INTRODUCTION}

Since $2011,25,000$ to 30,000 foreign fighters from as many as 100 countries have travelled to take part in conflicts in Syria and Iraq. ${ }^{1}$ Half originate from nearby Middle-Eastern and North African countries, with a further 21 per cent from Europe. ${ }^{2}$ This phenomenon has given rise to heightened concerns about the threat of terrorism in many Western nations.

The fear is that these fighters will return home with a radical outlook and the training needed to carry out terrorist attacks. ${ }^{3}$ In September 2014, the UN Security Council expressed concern that foreign fighters 'may pose a serious threat to their States of origin, the States they transit and the States to which they travel, as well as States neighbouring zones of armed conflict'. ${ }^{4}$ The Council called upon States to cooperate to restrict the movement of foreign fighters.

* Senior Research Associate, Andrew and Renata Kaldor Centre for International Refugee Law, Faculty of Law, University of New South Wales, sangeetha.pillai@unsw.edu.au.

** Dean, Anthony Mason Professor and Scientia Professor, Faculty of Law, University of New South Wales; Foundation Director, Gilbert + Tobin Centre of Public Law; Australian Research Council Laureate Fellow; Barrister, New South Wales Bar, george.williams@unsw.edu.au.

${ }^{1}$ A large proportion of these, some 7000 people, arrived as new recruits over the first half of 2015: see Institute for Economics and Peace, 'Global Terrorism Index' (November 2015) 3.

2 ibid 4. See also Z Laub and J Masters, 'Council on Foreign Relations Backgrounders: The Islamic State' (16 November 2015) at <http://www.cfr.org/iraq/islamic-state/p14811>.

3 See L Vidino, A Snetkov and L Pigoni, 'Foreign Fighters: An Overview of Responses in Eleven Countries' (Zurich Centre for Security Studies, March 2014) 4.

4 United Nations, Security Council Resolution 2178 (2014), S/RES//2178 (24 September 2014). 
Many Western nations have a broad range of laws that can be applied to meet this threat. ${ }^{5}$ These include offences, often introduced in the years following the 11 September 2001 attacks, of preparing for or carrying out a terrorist act. Intelligence and law-enforcement agencies have been conferred with expanded powers of questioning and surveillance. More recently, counterterrorism strategies have focused on restricting access to State territory. While initially such restrictions applied only to non-citizens, via immigration law, ${ }^{6}$ they have been extended to apply to citizens. One mechanism for doing this is to limit the right to a passport. ${ }^{7}$ Another, with more extreme effect, is to restrict the right to citizenship itself, by 'denationalizing' citizens who the State deems threatening.

Denationalization has gained popularity as a response to radicalization within the populace. ${ }^{8}$ Such laws necessarily affect a broad range of entitlements and rights that depend upon citizenship, including rights of protection, entry and exit and political participation. Not surprisingly, citizenship stripping as a response to security threats is hotly debated. Some commentators regard it as an illegitimate expansion of power 'at the expense of all citizens and of citizenship itself' ${ }^{9}$ Others suggest that denationalization is, in principle, a suitable mechanism for dealing with citizens who seek to commit acts of terrorism against their own State. ${ }^{10}$

In this article, we examine security-based citizenship revocation in the context of common law countries. ${ }^{11}$ We look in detail at the UK, Canada and Australia, as these are the only common law countries to have recently employed citizenship stripping in response to contemporary national security

5 See generally V Ramraj et al. (eds), Global Anti-Terrorism Law and Policy (2nd edn, Cambridge University Press 2012); K Roach (ed), Comparative Counter-Terrorism Law (Cambridge University Press 2015).

6 See B Hudson, 'Punishing Monsters, Judging Aliens: Justice at the Borders of Community' (2006) 39(2) Australian \& New Zealand Journal of Criminology 232-47.

7 See L Zedner, 'Enemies of the State: Curtailing Citizenship Rights as Counterterrorism', Max Weber Lecture, European University Institute (18 March 2015).

${ }^{8}$ Countries that in the last two years have enacted citizenship stripping laws as a response to security threats include Austria, Azerbaijan, Belgium and The Netherlands: See Nationality Act (Austria), art 33(2) (entered into force 2015); A Hasanli, 'Azerbaijanis engaged in terrorist activity to lose citizenship', Trend News Agency, 4 December 2015; Code of Belgian Nationality, art 23/2 (entered into force 2015); Citizenship Act (Netherlands), art 14(2)(b) (entered into force 2016). Other countries have renewed their use of such laws during this period. For instance, in 2015 section 8B of the Danish Nationality Act 2003 was applied for the first time to revoke the citizenship of Said Mansour: see Director of Public Prosecutions v Mansour [2015] IECA 213. This decision was upheld on appeal by the Danish Supreme Court in June 2016: see Supreme Court Verdict (8 June 2016), Case No 211/2015.

9 See eg A Macklin, 'Kick-off Contribution' in A Macklin and R Bauböck (eds), 'The Return of Banishment: Do the New Denationalisation Policies Weaken Citizenship?' (2015) Robert Schuman Centre for Advanced Studies Working Paper 2015/14 <http:/cadmus.eui.eu/bitstream/handle/ 1814/34617/RSCAS_2015_14.pdf?sequence=1 $>6$.

10 See eg C Joppke, 'Terror and the Loss of Citizenship' (2016) Citizenship Studies 16.

11 As we are primarily concerned with the evolution of citizenship stripping as a national security device, other grounds for citizenship revocation, such as fraud and misrepresentation, are considered only in passing. 
challenges. ${ }^{12}$ In each of these nations, security-based citizenship revocation is not unprecedented, having been employed during and after World Wars I and II. However, the recent revival of the practice is nonetheless remarkable, as it follows decades of disuse in each country.

Our analysis proceeds in four parts. We begin by setting out the key features that characterize the State-citizen relationship at common law. Secondly, we outline the historical evolution of citizenship legislation in each of the three countries, and consider the extent to which common law principles have continued to be reflected in such legislation. We then provide a detailed account of the development of the recent revocation laws as a response to security concerns, and the justifications provided for such laws. In doing so, we analyse the extent to which these recent laws represent a retreat from common law conceptualizations of citizenship. We conclude by discussing the impact that this recent shift towards citizenship stripping may have on future understandings of citizenship.

\section{THE COMMON LAW FRAMEWORK}

The models of citizenship in the UK, Canada and Australia share roots in the common law's conceptualization of the relationship between individuals and the State. Typically, the common law uses the language of 'subjecthood' rather than 'citizenship' to describe this relationship, although the terms 'subject' and 'citizen' are sometimes used interchangeably by scholars. ${ }^{13}$

The relationship between subjects and the State at common law experienced its most significant evolution between the fourteenth and nineteenth centuries, when 'British subject status' emerged as the gateway to formal community membership. Over this period, a pronounced common law distinction between 'British subjects' and 'aliens' emerged. This was first reflected in the conferral of various legal privileges, particularly relating to inheritance, on many UK-born residents, at the expense of foreign-born residents. ${ }^{14}$ In 1315 , the statute De Natis Ultra Mare was passed to increase legal protection for children born to persons engaged in foreign service. This statute reformed inheritance law by extending inheritance rights for foreign-born persons

12 Citizenship revocation has been enacted in other common law nations, but not as a response to recent national security concerns. For example, in New Zealand section 16 of the Citizenship Act 1977 enables revocation for dual citizens who have 'voluntarily exercised any of the privileges or performed any of the duties' of their foreign citizenship 'in a manner that is contrary to the interests of New Zealand'. This power extends to persons who have voluntarily and formally acquired the nationality or citizenship of a foreign country other than by marriage, and have subsequently acted in any manner contrary to the interests of New Zealand. This power was not introduced in response to contemporary events, nor has New Zealand moved to expand its citizenship revocation powers in recent times.

${ }_{13}$ See eg JW Salmond, Jurisprudence or the Theory of the Law (Stevens \& Haynes 1902) 192.

14 See eg F Pollock and FW Maitland, The History of English Law Before the Time of Edward I (Liberty Fund 2010 [1895]) vol 1, 269. 
whose parents were 'of the faith and [allegiance] of the King'. ${ }^{15}$ However it also had a significant influence on the subsequent development of nationality under common law, which was increasingly regarded by fifteenth and sixteenth century jurists as defined by reference to 'allegiance'. ${ }^{16}$

The anchorage of common law nationality on allegiance was affirmed in 1608 in Calvin's Case,${ }^{17}$ which concerned the legal status of Scottish-born persons, following the unification of England and Scotland under James I. In his leading judgment, Lord Coke affirmed that all persons born in Scotland after unification owed 'allegiance' to the King in his personal capacity. ${ }^{18}$ Consequently such persons qualified as 'subjects' rather than 'aliens'. ${ }^{19}$ While a person's 'allegiance' was acquired at birth, and therefore typically defined by their place of birth, Coke recognized exceptions to this rule that made it clear that subject status stemmed from allegiance rather than birthplace. For instance, persons born within the UK but without allegiance-such as the children of enemy aliens - were not regarded as subjects, ${ }^{20}$ while people who did not owe allegiance at birth could acquire it via letters patent, statutory provision or territorial acquisition. ${ }^{21}$

In addition to tethering subjecthood to allegiance, Coke conceived of the State-subject relationship as reciprocal. In exchange for a subject's duty of allegiance, the State owed a duty of protection. Coke described this relationship as a 'mutual bond and obligation between the King and his subjects'. ${ }^{22}$ Due to a paucity of case law on the rights and duties of subjecthood or citizenship, the substance of these reciprocal rights and duties has never been well defined. The parameters of the State's duty of protection, which has typically been treated as legally unenforceable, ${ }^{23}$ are particularly unclear. ${ }^{24}$ However, the idea that the State-citizen relationship is reciprocal in nature has endured, and has been repeatedly affirmed. ${ }^{25}$

The final core feature of the common law State-subject relationship that Lord Coke identified in Calvin's Case is that the bond between State and subject is permanent. This permanence distinguished the position of subjects from that of aliens, who also owed a temporary duty of 'local allegiance' to the State while

\footnotetext{
15 See eg F Plowden, A Disquisition Concerning the Law of Alienage and Naturalization (A Belin 1818) 40.

16 See eg K Kim, Aliens in Medieval Law: The Origins of Modern Citizenship (Cambridge University Press 2000) 141-2, 151-70.

17 Calvin v Smith (1608) 77 Eng Rep $377 . \quad 18$ ibid 388-9, 391.

19 ibid. See also JM Jones, British Nationality Law (Clarendon Press 1956) 54.

20 Jones (n 19) 56.

21 ibid 61. See also C Parry, Nationality and Citizenship Laws of the Commonwealth and the Republic of Ireland (Stevens \& Sons 1957) 43.

22 Calvin v Smith (1608) 77 Eng Rep 377, 382. $\quad 23$ See eg Salmond (n 13) 243.

24 See eg PJ Price, 'Natural Law and Birthright Citizenship in Calvin's Case (1608)' (1997) 9 YaleJL\&Human 73, 120.

25 See eg Ex parte Anderson (1861) 121 ER 525; China Navigation Co v Attorney-General (1932) 48 TLR 375; Attorney-General v Nissan [1969] 1 All ER 629; Oppenheimer v Cattermole [1972] 3 All ER 1106.
} 
within its borders, and were entitled to State protection during this time in return. In the case of an alien, both the duty of allegiance and the corresponding State duty of protection cease when the alien leaves State territory. In the case of a subject, however, both duties endure, wherever the subject happens to be. ${ }^{26}$

There has been little judicial consideration of the withdrawal of either allegiance or State protection. However, the jurisprudence that does exist emphasizes the continuity of the State-subject relationship. A number of cases and commentaries suggest that a State failure to provide protection does not terminate a subject's duty of allegiance. ${ }^{27}$ Similarly, obiter dicta from the case of Johnstone $v$ Pedlar ${ }^{28}$ suggests that an individual's failure to act 'in the spirit' of their duty of allegiance does not permit the withdrawal of State protection. In that case, Viscount Finlay stated that a British subject who commits treason 'remains for all purposes a British subject and must be treated as such in every respect', irrespective of whether subjecthood was acquired by birth or naturalization. ${ }^{29}$

Three key principles arise from these common law authorities. First, the State and its citizens owe each other reciprocal duties of protection and allegiance. Secondly, the State-citizen relationship is a secure one, which endures when one of these duties is breached. Finally, these principles apply equally to all citizens, regardless of how they obtained citizenship.

\section{EVOLUTION OF CITIZENSHIP REVOCATION LEGISLATION IN THE UK, CANADA AND}

\section{AUSTRALIA}

In 1844 , legislation was passed in the UK to allow aliens to take an oath of allegiance and become naturalized as subjects. ${ }^{30}$ Since then, statute has overtaken the common law as the predominant source of nationality law in the UK and former colonies such as Canada and Australia.

The UK nationality legislation enacted in the second half of the nineteenth century did not seek to overhaul common law understandings of subjecthood, but was designed to update nationality law to fit the political concerns of the day. ${ }^{31}$ The first major piece of UK nationality legislation was the Naturalization Act 1870, which allowed British subjects to elect to renounce their subjecthood by declaring themselves to be aliens. ${ }^{32}$ This eroded the common law idea that the bond between a subject and the State was permanent, but maintained the security of subjecthood as a status that a person could not lose against their will.

26 See Calvin v Smith (1608) 77 Eng Rep 377, 384-386.

27 See eg De Jager v Attorney-General of Natal [1907] AC 326. China Navigation Company v Attorney-General [1932] 2 KB 197, 211-213; G Williams, 'The Correlation of Allegiance and Protection' (1948) 10 CLJ 54, 57.

${ }^{28}$ [1921] 2 AC 262. ${ }^{29}$ ibid 274. ${ }^{30}$ See Parry (n 21) $69 . \quad 31$ ibid 72. $\quad 32$ ibid 79-80. 
Later statutory innovations in the UK threatened the security of citizenship by allowing the State to revoke a person's citizenship in particular circumstances. Such revocation powers were first mooted in 1870, when legislation to enable the Home Secretary to revoke the citizenship of a naturalized citizen who 'acted in a manner inconsistent with his allegiance' was proposed. This proposal was ultimately rejected, with parliamentarians criticizing the power on the grounds that it was 'transcendental', 'arbitrary', lacked safeguards, and created inequalities between natural born and naturalized British citizens. ${ }^{33}$ A limited power to revoke citizenship was finally introduced in 1914, when the Secretary of State was granted a power to revoke the citizenship of a naturalized person where it had been acquired by fraud, false representation or concealment of material circumstances. ${ }^{34}$

In 1918 , the grounds for citizenship revocation were extended to include disloyalty or a lack of allegiance, following public and political pressure to deal with enemies in the country's midst throughout World War I. ${ }^{35}$ Under these extended grounds, the Home Secretary was required to deprive a naturalized person of their British citizenship where they had shown themselves 'by act or speech to be disaffected or disloyal to [the Sovereign]'. ${ }^{36}$ Without limiting this, revocation was expressly required where the Secretary was satisfied of particular circumstances, and regarded retention of citizenship as being 'not conducive to the public good'. These circumstances were where a person was of 'bad character' at the time of naturalization, where they had resided in a foreign country for seven years or more without maintaining a 'substantial connection' with the UK or its dominions, where they had engaged in particular criminal behaviour, where they had traded or communicated with an enemy country or a citizen of such a country, or where they were a citizen of a country at war with the UK. ${ }^{37}$

At the onset of World War I, neither Canada nor Australia had developed an independent citizenship status. In both countries, British subject status, which could be obtained by birth or naturalization, was the highest formal membership status that a person could hold. ${ }^{38}$ In each country the grounds for revoking subjecthood for naturalized persons broadly mirrored those in place in the

33 See eg HL Debate, vol 199, cc 1604-1618 (10 March 1970).

34 See British Nationality and Status of Aliens Act 1914, section 7(1).

35 See eg P Panayi, The Enemy in Our Midst: Germans in Britain during the First World War (Berg 1991) 62-9.

36 British Nationality and Status of Aliens Act 1914, section 7(1), as amended by British Nationality and Status of Aliens Act 1918, section 1.

37 ibid section 7(2), as amended by British Nationality and Status of Aliens Act 1918, section 1.

38 For Canada, see A Macklin, 'Citizenship Revocation, the Privilege to Have Rights and the Production of the Alien' (2014) 40(1) Queens Law Journal 1, 21. For Australia, see K Rubenstein, "From This Time Forward ... I Pledge My Loyalty to Australia": Loyalty, Citizenship and Constitutional Law in Australia' in V Mason and R Nile (eds), Loyalties: Symposia Series (API Network Press 2005) 23, 24. 
UK: prior to World War I the only basis for revocation was fraud, ${ }^{39}$ but after the war both countries extended statutory powers to allow for disloyalty-based revocation.

In Canada, disloyalty-based revocation was introduced in 1919 and 1920, and directly mirrored the denaturalization legislation in the UK at the time. ${ }^{40}$ These laws were only passed through Parliament after substantial debate. Critics expressed several concerns: that the grounds of 'disaffection' and 'disloyalty' were too vague, ${ }^{41}$ that the ministerial discretion to revoke citizenship was too broad, and created 'fair weather citizens', whose status could be revoked at will, ${ }^{42}$ that persons considered too dangerous to live freely in Canada should be tried and incarcerated rather than deported, ${ }^{43}$ and that revocation decisions should lie with the judiciary rather than the executive. ${ }^{44}$ In response, the government asserted that the expanded revocation grounds were necessary in order to maintain compliance with UK naturalization law. ${ }^{45}$

In Australia, the idea of broadening revocation grounds was met with greater legislative enthusiasm, and was implemented earlier than in the UK and Canada. In 1917, legislative amendments allowed a naturalized person to have their subjecthood revoked on unrestricted grounds. ${ }^{46}$ However, new legislation in 1920 narrowed this power to conform with the revocation grounds in place in the UK and Canada. ${ }^{47}$

In all three countries, the expanded revocation grounds were used actively in the aftermath of World War I. The UK and Australia denaturalized around $50^{48}$ and $150^{49}$ people respectively during this time, with much more infrequent use of the power during the $1920 \mathrm{~s}^{50}$ In Canada, the power was used much more extensively, particularly once World War I had ended. Ninette Kelly and Michael Trebilcock have noted that between 1930 and 1936, 461 people had their naturalization certificates revoked. More than half of these revocations occurred in 1932 following a 'crackdown on the Communist Party'. 51

39 For a comprehensive overview of early Canadian legislation, see C Anderson, 'A LongStanding Canadian Tradition: Citizenship Revocation and Second-Class Citizenship under the Liberals, 1993-2006', Paper presented at the Canadian Political Science Association, York University (June 2006) < https://www.cpsa-acsp.ca/papers-2006/Anderson.pdf $>6$. In Australia, see Naturalization Act 1903 (Cth) section 11.

40 See Anderson (n 39) 6.

41 See eg Canada, House of Commons Debates, 26 June 1919, 4119 (Ernest Lapointe).

42 ibid, 26 June 1919, 4126 (Samuel Jacobs). $\quad{ }^{43}$ ibid, 21 June 1919, 3818 (Jacques Bureau).

44 ibid.

${ }^{45}$ See Anderson (n 39) 7.

46 See Naturalization Act 1917 (Cth) section 7, amending Naturalization Act 1903 (Cth) section 11.

47 See eg Nationality Act 1920 (Cth) section 12.

48 See M Gibney, 'The Deprivation of Citizenship in the United Kingdom: A Brief History' (2014) 28(4) Immigration, Nationality and Asylum Law 326, 328.

49 D Dutton, 'A Guide to Commonwealth Government Records in Australia', National Archives of Australia Research Guide (2000) < http:/guides.naa.gov.au/citizenship/chapter2/revocationnaturalisation.aspx $>$ ch 2 . $\quad 50$ See eg Gibney (n 48) 328; Dutton (n 49) ch 2.

51 N Kelley and M Trebilcock, The Making of the Mosaic: A History of Canadian Immigration Policy (University of Toronto Press 1998) 227. 
The revocation legislation introduced during and soon after World War I was employed again for World War II in each country. ${ }^{52}$ Once again, Canada made the most extensive use of the revocation powers: in the aftermath of World War II, denaturalization legislation and the emergency War Measures Act 1914 were used to support a government policy to 'repatriate' Canadians of Japanese descent, including those born in Canada, some of whom had never been to Japan. This scheme was critiqued in Parliament, with opponents suggesting that deporting Canadians was 'the very antithesis of the principles of democracy, ${ }^{53}$

Following World War II, citizenship revocation on disloyalty grounds reduced considerably. This was coupled with a narrowing of revocation grounds in all three countries, though in this instance a different legislative approach was adopted in each.

In the UK, the British Nationality Act 1948 retained the Secretary of State's capacity to revoke the citizenship of naturalized citizens on grounds of fraud and misrepresentation, ${ }^{54}$ as well as on narrowed disloyalty grounds. Under this Act it was no longer possible for the Secretary to revoke a person's citizenship on the basis of 'bad character' or citizenship of a State at war with the UK. The other disloyalty based grounds for revocation in the 1918 Act were retained, 55 however deprivation was only permitted where the Secretary was satisfied that retention of citizenship would be 'not conducive to the public good'. ${ }^{56}$ In 1964, these grounds were narrowed further: the capacity to revoke citizenship on the basis of residence in a foreign country was removed, and it became unlawful to revoke a person's citizenship on criminal grounds if this would render them stateless. This was done in order to make British law consistent with the 1961 UN Convention on the Reduction of Statelessness. ${ }^{57}$

Following World War II, the use of citizenship deprivation powers against disloyal citizens decreased considerably, to the point where the powers came to be considered 'moribund'. ${ }^{58}$ Although the power to revoke citizenship on disloyalty grounds remained available under UK legislation, the last instance of this power being invoked in the twentieth century took place in 1973.59

In 1981, UK nationality law was redrafted as the British Nationality Act 1981. Following vigorous parliamentary debate, ${ }^{60}$ a deprivation power, expressed in the same terms as under previous legislation, but without the protection against statelessness, was included in the new legislation. However, this power was never used.

\footnotetext{
52 For the UK, see Gibney (n 48) 328. For Canada, see Anderson (n 39) 7. For Australia, see Dutton (n 49) ch 2.

53 See Macklin, 'The Privilege to Have Rights' (n 38) 21-2 (quoting John Diefenbaker).

54 See British Nationality Act 1948, section 20(2). 55 ibid sections 20(3), 20(4).

56 ibid section 20(5). $\quad 57$ Gibney (n 48) $329 . \quad 58$ ibid 330.

59 The last citizen deprived of citizenship was Nicholas Prager, for spying for Czechoslovakia: See HL Deb vol 639 col 281 (9 October 2002); Gibney (n 48) 329.

${ }^{60}$ See eg HL Debate vol 423, cc 366-411 (23 July 1981); vol 424, cc 261-365 (13 October 1981).
} 
Canada and Australia legislated to create independent citizenship statuses by way of the Canadian Citizenship Act 1946 and Nationality and Citizenship Act 1948, respectively. Both acts initially provided wide grounds for citizenship revocation. In Canada, these mirrored the grounds in the UK legislation in force at the time, ${ }^{61}$ whereas in Australia, the revocation grounds under preexisting Australian naturalization legislation were retained. ${ }^{62}$ However, in contrast to the UK's decision to retain relatively broad statutory revocation powers, even once they had fallen into disuse, both Canada and Australia eventually moved to significantly restrict the grounds for citizenship stripping.

In Australia, amendments introduced in 1958 considerably limited the grounds for citizenship loss, ${ }^{63}$ and narrow grounds remained in place until the most recent changes to citizenship law. A person could have their citizenship revoked if they committed a serious offence in relation to their application for citizenship, ${ }^{64}$ or where their citizenship was obtained by fraud. ${ }^{65}$ Additionally, those who obtained their citizenship by application and 'conferral' could have it revoked if they were convicted of a 'serious offence' in the period between lodging an application for citizenship and having citizenship conferred, provided this would not render them stateless. ${ }^{66}$ In all these cases, revocation took place via the exercise of ministerial discretion, which required the Minister to be satisfied that it would be 'contrary to the public interest' for the person to remain an Australian citizen. ${ }^{67}$ In addition, an Australian citizen with dual citizenship automatically lost their Australian citizenship if they 'serve[d] in the armed forces of a country at war with Australia'.68 This provision has been part of Australian citizenship legislation since the 1948 Act was passed, but has never operated to deprive a person of their citizenship. ${ }^{69}$

In Canada, the 1946 Act was subsequently replaced with the Canadian Citizenship Act 1977. Secretary of State James Faulkner emphasized that this was intended to diminish government discretionary power, and promote equality and the rule of law. ${ }^{70}$ The Act retained ministerial powers to revoke citizenship on the basis of fraud ${ }^{71}$ or concealing material circumstances, ${ }^{72}$ but removed all other grounds for involuntary citizenship loss, including all disloyalty based grounds. As in Australia, this remained the approach to

61 See Canadian Citizenship Act 1946, pt III.

62 See Nationality and Citizenship Act 1948, div 4.

63 See Nationality and Citizenship Act 1958, sections 6, 7, amending Nationality and Citizenship Act 1948 sections 20-22.

64 See Australian Citizenship Act 2007, section 34(1)(b). $\quad 65$ ibid section 34(2)(b)

66 ibid section 34(2)(b) (ii). $\quad 67$ ibid sections 34(1)(c), (2)(c). 68 ibid section 35.

69 See eg K Rubenstein, Submission to Parliamentary Joint Committee on Intelligence and Security, Inquiry into the Australian Citizenship Amendment (Allegiance to Australia) Bill 2015 at $<$ http://www.aph.gov.au/Parliamentary_Business/Committees/Joint/Intelligence_and_Security/ Citizenship_Bill/Submissions $>4$.

${ }^{70}$ See Anderson (n 39) 9. $\quad 71$ Citizenship Act 1977, section $10 . \quad 72$ ibid section 18. 
citizenship revocation until the very recent enactment of new citizenship stripping laws.

The introduction of nationality legislation in the UK did not signify a radical break from common law principle, but rather a progressive development that built upon common law understandings of the subject-State relationship. Thus, common law subjecthood forms the foundation for citizenship in the UK, as well as the derivative concepts of citizenship that evolved in Canada and Australia. However, statutory citizenship in these three countries has at times developed inconsistently with common law principles.

The idea that the State-citizen bond is permanent experienced an early erosion. Citizens in all three countries have had a long-standing capacity to voluntarily renounce their citizenship. Moreover, in each country legislation has allowed for people to lose their citizenship involuntarily. In the context of World Wars I and II, such laws conferred broad executive revocation powers, which were often used. This undermined the common law idea of citizenship as a secure status, guaranteed to those who hold it: citizenship was instead made conditional on the conduct of the holder. This legislation also undermined the idea that all citizens hold an equal status, as only naturalized citizens were vulnerable to revocation. The 1917 Australian law conferring an unrestricted executive power to revoke the citizenship of a naturalized person, although wound back quickly, was an extreme example of this.

The idea that the State protection that stems from citizenship is owed in reciprocity to a citizen's duty of allegiance was better preserved, but ultimately still weakened by the wartime revocation laws. While a broad disloyalty based revocation ground existed, certain conduct that triggered revocation, such as residing in a foreign country without maintaining a connection with the State, and trading or communicating with a citizen of a country at war with the State, was not predicated on non-allegiance.

Notably, however, in the latter half of the twentieth century all three countries significantly narrowed citizenship stripping laws, and the use of such laws, in a way that substantially restored the connection with common law principles. Citizenship shifted from the 'conditional' status it had during times of emergency to a status that was generally very secure. This was most pronounced in Canada, where the narrowed laws only allowed people who obtained citizenship through fraud or material concealment of circumstances to lose it involuntarily. In the UK and Australia legislative grounds for disloyalty based citizenship loss remained, but were so narrow that they were never used in Australia, and were broader, but again not used, in the UK.

Similarly, the idea of citizenship as a compact involving reciprocal duties of allegiance and protection was restored. In each of the three countries, the continued centrality of a 'duty of allegiance' to citizenship has been affirmed, at least symbolically. Those who obtain citizenship by naturalization must take 
an oath affirming their allegiance or loyalty to the State. ${ }^{73}$ The idea that this allegiance is coupled with a reciprocal State duty of protection is also reflected, albeit more subtly. In the UK, while courts have stopped short of identifying a legally enforceable State duty to protect citizens, they have held that citizens may have a legitimate expectation that the State will consider extending protection to them. ${ }^{74}$ In Canada, State duties of protection are more tangibly codified in the Charter of Rights and Freedoms, which constitutionally guarantees freedom of movement to, from and within Canadian territory to all citizens. ${ }^{75}$ In Australia, the Preamble to the Australian Citizenship Act 2007 describes Australian citizenship as 'a bond, involving reciprocal rights and obligations'.

The idea that citizenship was an equal status was also revived. The principle of equal citizenship is most strongly reflected in Canada, where section 15 of the Charter of Rights and Freedoms guarantees equality under the law to all individuals. ${ }^{76}$ The Preamble to the Australian Citizenship Act 2007 describes citizenship as a 'common bond ... uniting all Australians', invoking, at least rhetorically, the idea of an equal citizenship.

Citizenship did not, however, become entirely equal. Only naturalized citizens could lose citizenship on account of fraud or failure to disclose material circumstances during the application process. In Australia, only dual citizens stood to lose their citizenship for serving in the armed forces of a country at war with Australia. UK legislation contained greater inequalities: broad security-based revocation powers only applied to those who obtained citizenship by naturalization or registration. However, despite these inequalities, the fact that the security-based denationalization grounds in Australia and the UK fell into disuse illustrates that, in practice if not in theory, citizenship was a status that applied equally, however it was obtained. ${ }^{77}$

73 See British Nationality Act 1981, section 42; Citizenship Act 1977, section 24; Australian Citizenship Act 2007, sched 1.

${ }^{74}$ See eg $R$ (Abbasi) v Secretary of State for Foreign \& Commonwealth Affairs [2002] EWCA Civ 1598.

75 Canadian Charter of Rights and Freedoms, art 6.

${ }^{76}$ This is not a provision that applies specifically to citizenship. However, it has been held to require non-discrimination in terms of access to citizenship in certain cases: See eg Benner $v$ Canada (Secretary of State) [1997] 1 SCR 358, 401. It has also been argued that section 15 protects against the establishment of 'second class citizenship': see eg Macklin, 'The Privilege to have Rights' (n 38) 48.

77 The fraud based grounds for citizenship revocation applied only to naturalized citizens, and were used with some regularity in all countries. However, it could be argued that as the basis for this revocation ground was that affected persons were never properly entitled to obtain citizenship in the first place, the argument that citizenship, once properly obtained, was an equal status can be maintained. 
IV. CITIZENSHIP STRIPPING REFORMS IN THE UK, CANADA AND AUSTRALIA

A. $U K$

\section{Overview}

The UK's citizenship stripping powers fell into disuse in the late twentieth century. In the twenty-first century, however, the UK has emerged as a global leader in using citizenship deprivation as a counterterrorism measure. In 2002, 2006 and 2014 it significantly broadened ministerial powers to revoke citizenship. As a result, it has been suggested that 'UK governments now have at their disposal laws to strip citizenship that are arguably broader than those possessed by any other Western democratic State'. ${ }^{78}$ Despite this, in October 2015, the British government announced a proposal to further expand the grounds for citizenship deprivation. ${ }^{79}$

The UK took its first step towards significantly expanding the statutory grounds for citizenship deprivation in 2002, in response to the September 11 terrorist attacks. Following the publication of a government White Paper recommending that denationalization laws be 'updated' and used to illustrate the State's 'abhorrence' of certain crimes, ${ }^{80}$ the Nationality, Immigration and Asylum Act 2002 made key expansions to the British Nationality Act. The power to denationalize a citizen was uncoupled from the precisely stated disloyalty grounds that had featured in earlier legislation. In place of such grounds, a single standard, characterized by increased executive discretion, was introduced, enabling citizenship deprivation whenever the Secretary of State believed that it would be 'seriously prejudicial to the vital interests of the United Kingdom' for a person to continue to hold citizenship. ${ }^{81}$ For the first time in UK legislation, this citizenship deprivation power was exercisable not only against naturalized British citizens, but also against natural born citizens - a change that was justified as a measure to avoid discrimination between the different classes of citizenship. ${ }^{82}$ However, in practice the power could only be applied to UK citizens (natural born or naturalized) with dual citizenship, as the legislation precluded denationalization where this would leave a person stateless. ${ }^{83}$

The substantial expansion of the grounds for citizenship revocation in the 2002 amendments marked a renewed shift away from the common law

78 See Gibney (n 48) 326.

79 See Great Britain, Home Office, 'Counter-Extremism Strategy' (October 2015) <https:// www.gov.uk/government/uploads/system/uploads/attachment_data/file/470088/51859_Cm9148_ Accessible.pdf $>$.

80 See Home Office, Secure Borders, Safe Haven: Integration with Diversity in Modern Britain (The Stationery Office 2002).

81 See Nationality, Immigration and Asylum Act 2002, section 4, amending British Nationality Act 1981, section 40 .

${ }^{82}$ See eg HL Debate, vol 679, col 281 (9 October 2002).

83 See Nationality, Immigration and Asylum Act 2002, section 4, amending British Nationality Act 1981, section 40(4). 
conceptualization of citizenship as a secure status. The Act also had implications for the equality between citizens. While it avoided earlier distinctions between natural born and naturalized citizens with respect to revocation, inequality between sole and dual citizens was created, with only the later class susceptible to citizenship revocation. On the other hand, the idea that the State-citizen relationship involves reciprocal duties of protection and allegiance was better preserved: to be a candidate for revocation, a person needed to act in a manner 'seriously prejudicial to the vital interests of the UK', action which would likely demonstrate a lack of allegiance.

Three days after the 2002 amendments entered into force, the Blair government sought to revoke the citizenship of Abu Hamza Al-Masri, a radical cleric who had publicly praised the September 11 terrorist attacks and Osama bin Laden. This marked the first attempt to invoke the government's citizenship deprivation powers in over 30 years. Ultimately, this effort was unsuccessful. ${ }^{84}$ Under the legislation at the time, deprivation did not come into effect until a person had exhausted all their appeal avenues. Abu Hamza lodged an appeal, which was not concluded until 2010. Within this time, Egypt had taken steps to divest him of his dual Egyptian citizenship. As a result, the Special Immigration Appeals Commission found that the Secretary of State lacked the power to revoke Abu Hamza's UK citizenship, as doing so would render him stateless. ${ }^{85}$

In 2006, following the 2005 London bombings, significant changes were introduced to lower the threshold for the exercise of citizenship deprivation powers, to any circumstance in which the Home Secretary believed that citizenship deprivation would be 'conducive to the public good'. ${ }^{86}$ Under this lowered threshold, citizenship revocation was no longer dependent on acting in a non-allegiant manner, signifying a further shift away from common law principle.

The 2006 amendments led to an immediate increase in deprivations, marking the first effective use of citizenship deprivation powers since $1973 .{ }^{87}$ However, citizenship stripping still remained relatively rare: between 2006 and 2009 only four people were denationalized. ${ }^{88}$ While citizenship revocation laws had departed in many respects from common law principles, this minimal use suggested that, at least in practice, UK citizenship initially remained a relatively secure status.

84 See C Woods and A Ross, "Medieval Exile": The 42 Britons stripped of their citizenship' The Bureau of Investigative Journalism (26 February 2013).

85 See Abu Hamza v Secretary of State for the Home Department, SC/23/2003, Special Immigration Appeals Commission, 5 November 2010 [22]. In 2004, in response to the Abu Hamza case, amendments were introduced to allow citizenship deprivation to take effect as soon as a notice to deprive was issued: see Gibney (n 48) 332.

86 See Immigration, Asylum and Nationality Act 2006, section 56, amending British Nationality Act 1981, section 40(2).

87 See M Gower, 'Deprivation of British citizenship and withdrawal of passport facilities', House of Commons Library Standard Note SN/HA/6820, 30 January 2015, 5. 
This security has waned since 2010, when the election of the Cameron government triggered a major shift in the exercise of citizenship deprivation powers. Within its first year, the government stripped six people of their citizenship. Since 2010, there have been 33 denationalizations on security grounds. ${ }^{89}$

In 2014, the UK Parliament enacted new changes allowing sole British citizens to be stripped of their citizenship. This occurred in the wake of a failed attempt to revoke the citizenship of Hilal al-Jedda, an asylum seeker from Iraq, who was granted British citizenship in 2000. Under Iraqi law at the time, al-Jedda automatically lost his Iraqi citizenship upon attaining a foreign citizenship. In December 2007, al-Jedda was notified that the Home Secretary considered that depriving him of his British citizenship would be 'conducive to the public good'. He appealed on the ground that such deprivation would leave him stateless. The matter reached the Supreme Court, before which the Home Secretary noted that, due to a change in Iraqi law after al-Jedda attained UK citizenship, he had the opportunity to reacquire Iraqi citizenship..$^{90}$ The Home Secretary argued that consequently, the deprivation order did not make al-Jedda stateless, as he was entitled to obtain another citizenship. The Court dismissed this submission, noting that it would 'mire the application of the [provision] in deeper complexity'. ${ }^{91}$ It unanimously found in al-Jedda's favour.

Following the al-Jedda case, the government sought to extend the UK's citizenship deprivation laws to enable certain terror suspects to be deprived of their UK citizenship, even if they would otherwise be left stateless. The proposal was a late addition to a package of broader amendments, and was introduced without prior consultation. ${ }^{92}$

This proposal met with considerable resistance in the House of Lords. In the course of a lengthy debate, crossbencher Lord Pannick, who led the opposition to the proposal, stated that ' $[\mathrm{t}]$ here are regrettably all too many dictators around the world willing to use the creation of statelessness as a weapon against opponents and we should do nothing to suggest that such conduct is acceptable'. ${ }^{93}$ The proposal also attracted criticism beyond Parliament. For instance, Ben Emmerson, the UN Special Rapporteur on Counter-Terrorism and Human Rights, said in evidence to the Parliamentary Joint Committee on Human Rights ('JCHR') that rendering individuals stateless is 'a subject of very serious concern'. ${ }^{94}$ The utility of the proposal as a national security measure was

${ }^{89}$ V Parsons, 'Citizenship stripping: new figures reveal Theresa May has deprived 33 individuals of British citizenship', The Bureau of Investigative Journalism (21 June 2016).

90 See Woods and Ross (n 84).

91 Al-Jedda $v$ Secretary of State for the Home Department [2013] UKSC 62, [32].

92 Joint Committee on Human Rights, Twelfth Report, Legislative Scrutiny: Immigration Bill (Second Report) (26 February 2014) 6 <http://www.publications.parliament.uk/pa/jt201314/ jtselect/jtrights/142/14205.htm>.

93 HL Deb vol 753 col 1169 (7 April 2014).

94 Joint Committee on Human Rights, Oral evidence from David Anderson QC, Independent Review of Terrorism Legislation; and Ben Emmerson QC, UN Special Rapporteur on Counter- 
also called into question. For instance, in the House of Lords debate, Baroness Kennedy observed that 'it is by no means clear what deprivation can achieve that the criminal law cannot'. 95

The House of Lords rejected the first iteration of the 2014 proposal. However, after a number of concessions by the government, the law was passed by both houses. As a result, section 40(4A) of the British Nationality Act provides that the Secretary of State may deprive a naturalized British citizen of their citizenship where he or she believes this would be 'conducive to the public good', even if that person would become stateless as a result. However, this power can only be exercised if the Home Secretary is satisfied that depriving the person of citizenship is 'for the public good' because, while they held citizenship status, they conducted themselves 'in a manner which is seriously prejudicial to the vital interests of the United Kingdom, any of the islands, or any British overseas territory'. Additionally, the Home Secretary must have reasonable grounds for believing that the person is able to become a national of a foreign country or territory under the law of that country or territory. ${ }^{96}$ As of April 2016, this power had not yet been used. ${ }^{97}$ Nonetheless, it further erodes equality between citizens, as only naturalized citizens are vulnerable to revocation with the more extreme consequence of statelessness.

The citizenship stripping legislation in force in the UK contains broad executive powers and limited safeguards. In a report on the 2014 Bill, the JCHR asked why the Bill did not provide for judicial involvement prior to a ministerial decision to revoke citizenship. The government responded that placing the court in the position of primary decision-maker would be 'out of step with all other immigration and nationality decisions' ${ }^{98}$ The JCHR recommended that, to mitigate arbitrariness, the Bill should be amended to require that, in cases involving statelessness, citizenship revocation be a 'necessary and proportionate response' to the prejudicial conduct engaged in by the citizen. This recommendation was not adopted. ${ }^{99}$

Individuals who have their citizenship revoked in the UK have a right of appeal, ${ }^{100}$ and are entitled to written notice outlining this right and the

Terrorism and Human Rights, 26 March 2014, <http://www.parliament.uk/documents/jointcommittees/human-rights/JCHR_HC_1202_TRANSCRIPT_Anderson_Emmerson_260314.pdf\$ 22 .

${ }_{95}$ HL Deb vol 753 col 46 (17 March 2014).

${ }^{96}$ For an analysis of the UK citizenship stripping provisions and the circumstances in which they are used, see Gower (n 87).

${ }_{97}$ See D Anderson QC, 'Citizenship Removal Resulting in Statelessness', First report of the Independent Reviewer on the operation of the power to remove citizenship obtained by naturalisation from people who have no other citizenship (April 2016) <https://www.gov.uk/government/uploads/ system/uploads/attachment_data/file/518120/David_Anderson_QC_-_CITIZENSHIP_REMOVAL web_pdf $>4 . \quad 98$ JCHR (n 92) [61].

${ }_{100}$ The right of appeal is to either a court (Immigration Act 2014 section $40 \mathrm{~A}(1)$ ) or the Special Immigration Appeals Commission (Special Immigration Appeals Commission Act 1997, section 2B), depending on whether the decision was made in reliance on closed material. 
reasons for the deprivation order. ${ }^{101}$ However, the efficacy of this appeal right can be limited. For instance, the right to appeal does not prevent a person from being subject to the consequences of citizenship deprivation, such as deportation from the UK, with no right to re-enter. This can make the practical exercise of appeal rights very difficult. Appeal rights are similarly difficult to exercise where a person is denationalized while they are outside UK territory. The Bureau of Investigative Journalism reported in 2013 that, in all but two cases, citizenship stripping powers had been exercised against individuals who were out of the UK. ${ }^{102}$

\section{Justifications}

Ministerial powers to revoke citizenship on disloyalty grounds have an almost century-long history in the UK. However, except during World Wars I and II, and since the Cameron government's time in office from 2009, these disloyalty based deprivation powers had been used sparingly, or not at all. On a number of occasions, the UK Parliament considered whether the powers to revoke citizenship on disloyalty grounds should be retained. It consistently opted to do so, despite the often restrained use of these powers. ${ }^{103}$ This was the case even in 1981, when citizenship stripping on disloyalty grounds had not occurred in close to a decade.

Many of the changes to the UK statutory citizenship stripping model demonstrate a desire to keep citizenship provisions 'up to date', perhaps to ensure that they remain tailored to the concerns of the day. The changes in 2002 - which enabled denationalization for 'natural born' UK citizens, and replaced the previously precise grounds for deprivation with a general revocation power exercisable where the Secretary of State was satisfied that a person had acted 'in a manner seriously prejudicial to the vital interests of the UK' - took place in the wake of the 11 September 2001 terrorist attacks in the US. The changes were justified on the basis that the configuration of the previous deprivation powers failed to reflect 'the types of activity that might threaten [the UK's] democratic institutions and [its] way of life'. ${ }^{104}$

A criticism of the 2002 law was that most conduct seriously prejudicial to the vital interests of the UK was already criminalized and penalized through treason offences. The government's response was that it wanted to retain the power to revoke citizenship even where a criminal conviction was not or could not be secured, for instance, due to a lack of sufficient admissible evidence. ${ }^{105}$

101 Immigration Act 2014, section 40(5).

102 A Ross and P Galey, 'Rise in citizenship-stripping as government cracks down on UK fighters in Syria', The Bureau of Investigative Journalism (23 December 2013). See also Gower (n 87) 5-7.

103 For justifications for retention in Parliament, see eg HL Deb vol 423 col 448 (23 July 1981) (Lord Mackay); HL Deb vol 639 col 279 (9 October 2002) (Lord Filkin).

104 House of Lords Select Committee on the Constitution, Nationality, Immigration and Asylum Bill, 6th Report, HL 129 (2002), 6.

${ }_{105}$ See eg S Mantu, 'Deprivation of citizenship in the United Kingdom', ENACT Project Deliverable WP4 (July 2009) 17. See also HL Deb vol 639 cc 280-281 (9 October 2002). 
Similarly, the lowering of the threshold in 2006 to allow deprivation wherever the Secretary of State believed it would be 'conducive to the public good' was designed to enable revocation for citizens who had not engaged in any criminal activity. This reflected the changes being immediately preceded by the 2005 London bombings, in which many of the perpetrators were previously unknown to police. ${ }^{106}$ The 2014 changes, enabling citizenship revocation even where statelessness may follow as a consequence, were produced by the government's ultimate loss in the protracted al-Jedda case. ${ }^{107}$

The UK citizenship revocation laws overlap with a wide range of other national security measures. Some of these measures produce the same outcomes as denationalization, such as the detention and removal of individuals deemed to pose a threat, often with greater practical effect. For instance, the Home Secretary enjoys under the Royal Prerogative an executive discretion to withdraw or refuse passports. Historically, these powers are thought to have been used very sparingly. ${ }^{108}$ However, in April 2013, the criteria for using the Prerogative were updated. ${ }^{109}$ Between the update and November 2014, Home Secretary Theresa May invoked the passport refusal and cancellation powers 29 times. ${ }^{110}$

In January 2015, the Counterterrorism and Security Act 2015 (CTSA) introduced a suite of new administrative powers designed to facilitate exclusion and to disrupt the mobility of persons deemed to pose a security risk. One of the key features of the CTSA is the Temporary Exclusion Order (TEO) - an order which the Home Secretary may issue to prevent a citizen outside the UK from returning to the UK for a two-year period. ${ }^{111}$ After, or during, this period additional TEOs may be imposed. ${ }^{112}$ In order to issue a TEO, the Home Secretary must be satisfied of five criteria. ${ }^{113}$ Most significantly, he or she must 'reasonably suspect that the individual is, or has been, involved in terrorism-related activity outside the United Kingdom', 114 and 'reasonably consider that it is necessary, for purposes connected with protecting members of the public in the United Kingdom from a risk of terrorism'. ${ }^{115}$

106 See eg 'Report of the Official Account of the Bombings in London on 7th July 2005', HC 1087 (2006). In the House of Lords, Baroness Ashton of Upholland defended the need for the lower threshold: 'Our experience, on looking back over cases from the past two or three years, is that the test is too high and the hurdles too great': HL Deb vol 679, col 1190.

107 See eg JCHR, n 92 [23]-[24].

108 For instance, the power is reported to have been used only 16 times between 1947 and 1976 : see eg Gower, (n 87) 9.

109 ibid 7.

110 The Rt Hon Theresa May MP, Speech on counter-terrorism, Royal United Services Institute, Whitehall (24 November 2014) at < https://www.gov.uk/government/speeches/home-secretarytheresa-may-on-counter-terrorism $>$.

111 TEOs can also apply to non-citizens who have a right of abode in the UK: see CounterTerrorism and Security Act 2015, section 2(6).

113 See ibid, sections 2(3)-2(7). 112 ibid section $4(8)$. 114 ibid section $2(3)$.

115 ibid section 2(4). Other conditions are that the Secretary of State reasonably considers that the individual is outside the UK: section 2(5), that the individual has a right of abode in the UK: section 2(6). 
Given that the majority of citizenship revocations are issued while a citizen is overseas, ${ }^{116}$ a TEO or passport cancellation order could also be used to prevent their return to the UK. For citizens within the UK, the revocation laws do open up the additional possibility of permanent removal. However, this is often not a practical goal. For instance, removing a person from the UK once they have had their citizenship revoked depends upon finding a country willing to take them. This is likely to be particularly challenging where revocation results in statelessness. However, even where this is not the case, deportation can prove practically difficult. For instance, in Pham v Secretary of State for the Home Department, ${ }^{117}$ the applicant was a naturalized British citizen who had never renounced his prior Vietnamese citizenship. The Home Secretary ordered that he be stripped of his British citizenship and deported to Vietnam. However, deportation was frustrated when the Vietnamese government responded that it did not recognize the applicant as a Vietnamese citizen. ${ }^{118}$ Cases such as this demonstrate the problematic nature of citizenship revocation as an effective counterterrorism tool, and why such a power may be of limited utility compared to other measures.

However, the UK's twenty-first century citizenship-stripping expansions were not strictly utilitarian in object. Proponents also advanced a rhetorical justification, asserting that the laws reinforced key features of the Statecitizen relationship. For instance, when defending the laws, government members described citizenship as a 'privilege' rather than a right, and emphasized that citizens owe a duty of allegiance to the State. ${ }^{119}$

Notably, these rhetorical defences of the new revocation laws have sought to invoke elements of the common law conceptualization of citizenship: particularly the idea that citizenship is based on allegiance. At the same time, the recasting of citizenship as a 'privilege' rather than a secure status actively undermines the other key features of common law citizenship - its reciprocity, its security and continuity as a status, and the idea that it is characterized by equality.

This distorted invocation of the common law, magnifying select principles while minimizing others, has the potential to radically alter the way in which UK citizenship is understood. This is bolstered by the fact that, as noted

Finally, the Secretary of State must either obtain permission to impose a TEO, or reasonably consider that the urgency of the case requires a TEO to be imposed without prior judicial permission: section 2 (7). Other features of the CTSA include police powers to seize and retain for up to 14 days the travel documents of a person 'suspected of intending to leave Great Britain ... in connection with terrorismrelated activity': section 1(1), and the resurrection of a previously abolished power by enabling people to be forcibly relocated under Temporary Prevention and Investigation Measures (TPIMs): Pt 2.

116 Ross and Galey (n 102). 117 [2015] UKSC 19. 118 ibid [3].

119 See eg HC Deb vol 384, col 413 (24 April 2002) (Marsha Singh); HC Deb vol 590 cc 170-210 (6 January 2015); A Worthington, 'The UK's Unacceptable Obsession with Stripping British Citizens of Their UK Nationality' (25 March 2014) <http://www.andyworthington.co.uk/2014/ 03/25/the-uks-unacceptable-obsession-with-stripping-british-citizens-of-their-uk-nationality/ \#sthash.1GLLqPHr.dpuf>. 
above, the revocation laws enacted by the UK in the twenty-first century reflect a progressive shift away from common law understandings of citizenship.

The idea that the UK's recent revocation expansions undermine the security and equality of citizenship is readily apparent. Perhaps less obviously these laws also mark a shift away from the idea that citizenship is tethered to allegiance. The current revocation threshold in UK law generally allows a person to be stripped of their citizenship whenever this would be 'conducive to the public good'. This does not require any nonallegiant conduct on the citizen's part. Thus, attempts to justify the revocation laws as an affirmation of the fact that citizens owe a duty of allegiance to the State do not seem to provide an adequate explanation for their enactment. Moreover, the fact that some citizens may be vulnerable to denationalization even where they have maintained their allegiance undermines the idea that the allegiance of citizens is offered in exchange for protection from the State.

In October 2015, the UK government released a new Counter Extremism Strategy, which signalled plans to 'consider ... how we can more easily revoke citizenship from those who reject our values'. ${ }^{120}$ The Strategy non-exhaustively defines 'values' as including 'the rule of law, democracy, individual liberty and the mutual respect, tolerance and understanding of different faiths and beliefs'. ${ }^{121}$ It seems clear that if this plan to expand denationalization grounds is ultimately implemented, UK citizenship will become less secure and more conditional. Beyond this, it is unclear what principles could inform where a revocation threshold might be drawn, but likely that a compelling justification for the laws would need to look beyond the common law rhetoric of citizenship being based on allegiance.

\section{B. Canada}

\section{Overview}

The first recent proposal to expand citizenship stripping legislation in Canada came in 2012, when a private members bill (Bill C-425) proposed an amendment providing that a Canadian with dual citizenship would be deemed to have renounced their Canadian citizenship upon engagement in an act of war against the Canadian Armed Forces. ${ }^{122}$ In February, Bill C-425 passed through the House of Commons. However, the Minister of Citizenship, Immigration and Multiculturalism, Jason Kenney, proposed that this be expanded to provide for dual citizens to be deprived of Canadian

120 See Great Britain, Home Office, ‘Counter-Extremism Strategy’ (n 79) 33. $\quad 121$ ibid 9.

122 Bill C-425, An Act to Amend the Citizenship Act (Honouring the Canadian Armed Forces), 2012, $\mathrm{cl} 2$. 
citizenship where they engage in acts of terrorism. ${ }^{123}$ This led to the replacement of Bill C-425 with the Strengthening Canadian Citizenship Act 2015. In an interview in February 2013, Kenney said that the legislation was intended to be largely 'symbolic', and that it would rarely be used. ${ }^{124}$

In mid-2014, the Strengthening Canadian Citizenship Act was passed. The Act expanded the grounds for revocation considerably to include three new circumstances. First, the Minister is empowered to revoke a person's citizenship where an individual is convicted of any of a series of prescribed offences under Canadian law relating to national security. ${ }^{125}$ Secondly, revocation is possible where a citizen is convicted in a foreign jurisdiction of an offence committed outside Canada that, had it been committed in Canada, would qualify as a 'terrorism offence' under section 2 of the Criminal Code. ${ }^{126}$ Finally, the Minister may revoke citizenship where he or she has reasonable grounds to believe that the person concerned, while holding Canadian citizenship, served in the armed forces of a country, or as a member of an organized armed group, while that country or group was engaged in armed conflict with Canada. ${ }^{127}$

Before exercising this final power, the Minister must obtain a judicial declaration that the person engaged in the activity in question. ${ }^{128} \mathrm{~A}$ degree of protection against statelessness is also provided for: the three new grounds for citizenship revocation do not authorize revocation that conflicts with any international human rights instrument regarding statelessness to which Canada is signatory. ${ }^{129}$ However, the person affected bears the burden of proving, on the balance of probabilities, that they are 'not a citizen of any country of which the Minister has reasonable grounds to believe the person is a citizen'. ${ }^{130}$

In most cases, the Strengthening Canadian Citizenship Act leaves the decision of whether or not a person's citizenship shall be revoked with the Minister, rather than with a court. However, the judiciary plays a role in the process in the sense that revocation must be preceded by either a conviction (albeit not necessarily in a Canadian court), or a judicial declaration that the citizen concerned has engaged in particular conduct. This requirement of both an executive and a judicial decision provides some safeguard against abuses of power.

Ministerial revocation decisions are also subject to judicial review. ${ }^{131}$ However, as in the UK, the ability to access such review may be limited where the citizen seeking review is outside national borders.

123 Evidence to House of Commons Standing Committee on Citizenship and Immigration, Parliament of Canada, Ottawa, 21 March 2013, (Jason Kenney) <http://www.parl.gc.ca/ HousePublications/Publication .aspx?Language $=\mathrm{e} \&$ Mode $=1 \&$ Parl=41\&Ses=1\&DocId=6054299> .

124 See M Shephard, 'Q\&A: Jason Kenney says bill to strip Canadian citizenship largely "symbolic", The Star (25 February 2013).

125 See Citizenship Act (Canada), section 10(2).

127 ibid section 10.1(2). ${ }^{128}$ ibid. 129 ibid section 10.4(1).

131 See ibid, section 22.1(1). 
Other potential safeguards may stem from Canada's constitutional framework, which includes a constitutionally entrenched Charter of Rights and Freedoms. ${ }^{132}$ While the Charter does not contain an express guarantee of citizenship, it enshrines a number of 'citizenship rights', including the right to vote in elections ${ }^{133}$ and the right to remain in, leave and return to Canada. ${ }^{134}$ It also contains a number of broader rights that apply to all persons. Significantly, section 15 of the Charter provides broad-ranging protection against discrimination in the context of every individual being 'equal before and under the law'. This arguably encompasses the common law idea that citizenship is an equal status for all holders. ${ }^{135}$

In September 2015, the Harper government revoked the citizenship of Zakaria Amara, the ringleader of the unsuccessful Toronto 18 bomb plot, who is currently serving a sentence of life imprisonment. ${ }^{136}$ Amara is the only person to have lost citizenship under the Strengthening Canadian Citizenship Act; however the Harper government also issued notices signalling an intention to denationalize nine other citizens, most of whom were also members of the Toronto 18 group. ${ }^{137}$ A number of constitutional challenges to the Act were initiated in response, including an argument that by limiting its application to dual citizens, the Act contravened the equality principles enshrined in section 15 of the Charter. ${ }^{138}$ However, following a change in government in 2015, discussed below, further revocations are unlikely to take place and these challenges have lapsed. ${ }^{139}$

\section{Justifications}

As in the UK, justifications for the Strengthening Canadian Citizenship Act took the form of rhetorical statements about the 'value' of Canadian citizenship. In his second reading speech, Immigration Minister Chris Alexander asserted that the Act was directed towards 'strengthen[ing] and protect[ing] the value of Canadian citizenship', ${ }^{140}$ and that it would help maintain the integrity of citizenship. ${ }^{141}$ At a press conference, Alexander said that '[c]itizenship is not

132 See Macklin, 'The Privilege to Have Rights' (n 38) 31-51.

133 Canadian Charter of Rights and Freedoms, section 3.

134 ibid section $6 . \quad 135$ See eg Macklin, 'The Privilege to Have Rights' (n 38 ) 48.

136 See eg The Canadian Press, 'Canada Revokes Citizenship Of Toronto 18 Plotter' The Huffington Post Canada (26 September 2015).

${ }_{137}$ See S Bell, 'Canada working to revoke the citizenship of nine more convicted terrorists' National Post (30 September 2015).

${ }^{138}$ See D Greer, “'Two-Tiered” Canadian Citizenship Challenged', Courthouse News Service (1 September 2015); J Bronskill, 'Ottawa man challenges federal move to revoke citizenship over terrorism' National Newswatch (1 October 2015); The Canadian Press, 'Terrorist says stripping citizenship violates his right to vote' Maclean's (15 October 2015).

139 See eg M Friscolanti, 'As Trudeau takes power, judge adjourns citizenship court battle' Maclean's (4 November 2015).

${ }_{140}$ Canada, House of Commons Debates, 27 February 2014, 1525 (Chris Alexander).

141 ibid 1530 (Chris Alexander). 
a right; it is a privilege'. ${ }^{142}$ When introducing the legislation into the upper house, Senator Nicole Eaton said:

Citizenship is based on allegiance. Those granted citizenship pledge allegiance to our monarch, the Queen of Canada, and to our system of government and its laws. Betrayal of this allegiance comes with a price. ${ }^{143}$

As in the UK, these statements draw heavily on the common law conceptualization of citizenship, by reinforcing the idea that citizenship is based on allegiance. However, they simultaneously subvert the common law, by downplaying the reciprocity and security of the State-citizen relationship, and shifting citizenship towards a conditional status that renders some citizens more vulnerable than others.

The Strengthening Canadian Citizenship Act aligns more closely with the rhetorical justifications provided than the UK revocation legislation. Enabling revocation only where a person has served with a country or group engaged in conflict with Canada or has been convicted or a terrorism or national security offence ensures that revocation generally is predicated on a lack of allegiance. However, parts of the Act remain unsupported by the allegiance justification. For instance, section 10(2) renders a person convicted of particular national security offences in a foreign country susceptible to revocation. While such conduct may be reprehensible, it does not inherently require any disloyalty to Canada. As in the UK, this undermines the idea that it is the State's duty to extend protection to citizens in exchange for their allegiance. Moreover, the idea that the citizenship of dual citizens is conditional upon particular behaviour, while that of sole citizens is not, undermines the idea that citizenship is an equal status.

In October 2015, a new government was elected in Canada, under the leadership of Justin Trudeau. In the lead-up to the election, Trudeau voiced his opposition to the Strengthening Canadian Citizenship Act, arguing that 'as soon as you make citizenship for some Canadians conditional on good behaviour, you devalue citizenship for everyone'. ${ }^{144}$ Like the justifications for the Act, Trudeau's opposition was anchored around a rhetorical point about the value of citizenship: one that reiterated the security and equality elements of common law citizenship that were minimized by proponents of the Act.

Since its election, the Trudeau government has taken steps to undo key elements of the Strengthening Canadian Citizenship Act. In February 2016, Bill C-6, was introduced into Parliament. The Bill purports to repeal all the new national security grounds for citizenship revocation, ${ }^{145}$ and to restore the

\footnotetext{
142 S Mas, 'New citizenship rules target fraud, foreign terrorism', CBC News (6 February 2014).

143 Canada, Senate Debates, 17 June 2014, 1540 (Nicole Eaton).

144 See eg R Maloney, 'Bill C-24: Trudeau Says Terrorists Shouldn't Be Stripped Of Citizenship In Leaked Audio' The Huffington Post Canada (28 September 2015).

145 Bill C-6, An Act to amend the Citizenship Act and to make consequential amendments to
} another Act, 2016, cll 3-5. 
citizenship of any person denationalized under those grounds. ${ }^{146}$ Accordingly, if the Bill becomes law Zakaria Amara will regain his Canadian citizenship.

Bill C-6 was passed by the House of Commons on 17 June 2016, and is currently before the Senate. As was the case with the Strengthening Canadian Citizenship Act, parliamentary debate over the Bill so far has focused overwhelmingly on the value of citizenship. The contrast between these two pieces of legislation showcases deep philosophical differences in the way in which the Harper and Trudeau governments have conceived of citizenship. In stark contrast to the rhetoric about citizenship being a 'privilege' that accompanied the introduction of the Strengthening Canadian Citizenship Act, the current government has defended Bill C-6 as a measure necessary to preserve the principles of secure citizenship and equality between all citizens, which stem from the common law. In his second reading speech for the Bill, Minister for Immigration, Refugees and Citizenship, John McCallum, said: '[w] hen we say a Canadian is a Canadian is a Canadian, that includes good and bad Canadians'. ${ }^{147}$ McCallum went on to say:

The place for a terrorist is in prison, not at the airport. It is our strong belief that if a person is sent to prison for terrorism, there should not be two classes of terrorists: those who go to prison and have their citizenship revoked and those who only go to prison. ${ }^{148}$

Though they did not invoke the common law citizenship rubric, those who argued against Bill C-6 also focused on maintaining the 'value' of Canadian citizenship. For instance Conservative MP Garnett Genuis said:

What this bill would do, in my view, is reduce the value of citizenship by allowing someone to be involved in terrorism, which completely goes against Canadian values ... This potentially toxic combination would reduce the value of our citizenship. ${ }^{149}$

Whether or not Bill C-6 passes is likely to have a significant effect on the way in which Canadian citizenship is conceptualized in the future. If the Bill ultimately becomes law, it will mark the restoration of a concept of citizenship that reflects common law principles. If, on the other hand, the changes implemented via the Strengthening Canadian Citizenship Act remain in place, Canadian citizenship will remain removed from its common law roots, and over time this distance may expand as the new revocation powers are employed or updated. The many references to 'citizenship values' in parliamentary debates also suggest that we may see a renegotiation of the values, beyond 'allegiance', that define what it means to be Canadian.

\footnotetext{
146 ibid cl 20. Fraud-based revocation, which predates the Harper government's changes, is retained.

147 Canada, House of Commons Debates, 9 March 2016, 1604 (John McCallum).

148 ibid $1605 . \quad 149$ ibid 1655 (Garnett Genuis).
} 


\section{Australia}

\section{Overview}

Australia is the most recent common law country to enact legislation enabling citizenship stripping on national security grounds. This move was motivated by the risks associated with Australian foreign fighter participation in the Syrian and Iraqi conflicts, by a reported increase in security risks within Australia, and by the use of citizenship stripping as a national security device in the UK and Canada.

In early 2015, the Australian government signalled its intention to expand the grounds for citizenship loss. In a national security address, then-Prime Minister Tony Abbott said that 'at least 110 Australians [had] travelled overseas to join the death cult in Iraq and Syria', and that within Australia there were 'over 400 high-priority counter terrorism investigations on foot'. ${ }^{150}$ Noting that 'all too often the threat comes from someone who has enjoyed the hospitality and generosity of the Australian people', ${ }^{151}$ Abbott announced plans to amend the law to allow citizenship revocation for dual citizens on terrorism-related grounds.

Deciding upon a model for the expanded citizenship stripping legislation was not a straightforward task. Initial statements by Abbott and Immigration and Border Protection Minister Peter Dutton suggested that the government hoped to introduce UK-style legislation, with a broad ministerial discretion to revoke citizenship, ${ }^{152}$ and that this power might be exercisable even against Australian citizens who held no other citizenship. However, legal experts pointed out that a sweeping executive power of this nature was unlikely to be constitutionally permissible in Australia ${ }^{153}$ Additionally, as outlined in detailed leaks from Cabinet, the suggestion that the Minister might have the power to strip sole Australian citizens of their citizenship met with substantial opposition from senior members of the government, who argued that the move would violate the rule of law and international law principles. ${ }^{154}$

In June 2015, the Abbott government introduced the Australian Citizenship Amendment (Allegiance to Australia) Bill 2015 (Cth) into Parliament. The Bill

150 The Hon Tony Abbott, 'National Security Statement', Speech delivered at Australian Federal Police Headquarters, Canberra (23 February 2015) <http://www.scribd.com/doc/256590320/ National-Security-Statement-Canberra>.

152 See P Dutton, Transcript of Interview on Sky News (27 May 2015), <http://www.minister. border.gov.au/peterdutton/2015/Pages/citizenship-khaled-sharoufs-family.aspx $>$.

153 See eg H Irving and R Thwaites, 'The Citizenship Amendment Bill: Out of the Frying Pan into the Fire', AUSPUBLAW (20 July 2015) < http://auspublaw.org/2015/07/the-citizenshipamendment-bill/>; S Pillai, 'The Allegiance to Australia Bill and the Constitution: Legislative Power and Membership of the Constitutional Community', AUSPUBLAW (21 July 2015) $<$ http://auspublaw.org/2015/07/the-allegiance-to-australia-bill-and-the-constitution/>.

${ }^{154}$ See eg P Hartcher and J Massola, 'Cabinet revolt over Tony Abbott and Peter Dutton plan to strip Australians of citizenship' The Sydney Morning Herald (26 May 2015). 
sought to provide for a dual citizen to lose their Australian citizenship where they had repudiated their allegiance to Australia. ${ }^{155}$ The Bill did not vest the Minister for Immigration with the expansive powers seen in UK legislation. Despite this, it set out the most wide-ranging citizenship stripping provisions so far proposed in any common law nation.

Rather than create either a ministerial or a judicial power to revoke citizenship, the Bill purported to create three 'self-executing' procedures by which automatic citizenship loss would be triggered. The first provided for a person to lose their citizenship automatically upon engagement in certain terrorism-related conduct, such as committing a terrorist act, financing terrorism or directing a terrorist organization. ${ }^{156}$ The conduct was defined by reference to specified criminal offences, though in doing so the Bill did not incorporate the specific defences to those crimes, nor other qualifying factors such as the age of criminal responsibility. ${ }^{157}$

Automatic loss of citizenship occurred when a person had engaged in the relevant conduct. This did not require a conviction in the courts (indeed, a person would even lose their citizenship where they had been acquitted of such a crime) or an executive determination that the citizen in question had engaged in the conduct. Nor did the Bill set out any hearing, appeal or other means by which an affected person might put their case. In fact, the Bill did not outline any fact-finding mechanism via which to determine that a person had committed relevant conduct, although it did provide a ministerial power to exempt a person from citizenship loss. The Minister was not required to consider whether to exercise this power of exemption, nor given prescribed criteria to take into account. ${ }^{158}$

A second 'self-executing' procedure, again based merely upon a person's conduct, would have expanded the existing ground of citizenship deprivation for serving in the armed forces of a country at war with Australia. ${ }^{159}$ This was to be extended to fighting for or being in the service of an organization declared to be a terrorist organization under Australian law. As the explanatory memorandum to the Bill made clear, being in the 'service' of such an organization would include the provision of medical support or other like assistance. ${ }^{160}$

The third new ground of automatic citizenship revocation was triggered by conviction, irrespective of the penalty imposed, of any one of a list of prescribed offences. ${ }^{161}$ The qualifying offences included a long list of crimes directly or indirectly connected with terrorism. However, it also included

\footnotetext{
155 See Commonwealth, Parliamentary Debates, House of Representatives, 24 June 2015, 7369 (Peter Dutton).

156 See Australian Citizenship Amendment (Allegiance to Australia) Bill 2015, cl 3.

157 ibid. $\quad 158$ ibid. 159 ibid cl 4.

160 Explanatory Memorandum, Australian Citizenship Amendment (Allegiance to Australia) Bill 2015 , [56].

161 Australian Citizenship Amendment (Allegiance to Australia) Bill 2015, cl 5.
} 
many offences that had no necessary connection to allegiance or national security. For instance, one of the offences giving rise to citizenship loss was the crime of 'damaging Commonwealth property'. ${ }^{162}$ As the Bill did not require that a minimum sentence be imposed for a person to lose their citizenship, this made it possible for petty criminals who posed no security risk-such as a person who graffitied a Commonwealth building, or punctured the tyres of a Commonwealth vehicle, to automatically lose their citizenship.

The ambit of these provisions was further extended by their potential application to the children of any person whose citizenship had been automatically revoked on any of these grounds. Irrespective of whether such children themselves had demonstrated any culpability or lack of allegiance, the Bill provided a mechanism by which the Minister could revoke their citizenship, once this had already been removed from their parent. ${ }^{163}$

While the title of the original Bill, and the Minister's comments in his second reading speech, suggest that it was designed to deprive people of their citizenship where they had breached their common law duty of allegiance, the provisions themselves provided for citizenship loss in a far wider range of circumstances. By setting up automatic citizenship stripping, rather than a revocation power, the Bill bypassed the need to undertake any holistic assessment of whether a person had repudiated their allegiance, before denationalizing them. This was exacerbated by the fact that the Bill clearly provided for automatic citizenship loss in circumstances involving no necessary repudiation of allegiance, such as where a person had damaged Commonwealth property.

The Bill was referred to an inquiry conducted by the Parliamentary Joint Committee on Intelligence and Security (PJCIS). Submissions to the inquiry resoundingly criticized the legislation. Legal experts noted that it was overly broad, poorly drafted, unclear in its application and constitutionally problematic. ${ }^{164}$ The Bill was also criticized for its lack of appropriate

162 ibid.

163 This was made clear in notes to the amendments proposed in cll 3, 4 and 5 of the Bill, and facilitated by section 36 of the Australian Citizenship Act 2007 (Cth) - a pre-existing provision that allows the Minister to revoke a child's citizenship in certain circumstances following a parent's loss of citizenship.

164 See eg S Chordia, S Pillai and G Williams, Submission to Parliamentary Joint Committee on Intelligence and Security, Inquiry into the Australian Citizenship Amendment (Allegiance to Australia) Bill 2015, 2-5; A Twomey, Submission to Parliamentary Joint Committee on Intelligence and Security, Inquiry into the Australian Citizenship Amendment (Allegiance to Australia) Bill 2015 generally; H Irving, Submission to Parliamentary Joint Committee on Intelligence and Security, Inquiry into the Australian Citizenship Amendment (Allegiance to Australia) Bill 2015, 1-4; Australian Bar Association, Submission to Parliamentary Joint Committee on Intelligence and Security, Inquiry into the Australian Citizenship Amendment (Allegiance to Australia) Bill 2015 generally; all accessible at <http://www.aph.gov.au/ Parliamentary_Business/Committees/Joint/Intelligence_and_Security/Citizenship_Bill/Submissions>. 
safeguards. ${ }^{165}$ It applied to children of all ages, excluded natural justice, did not require a person to be informed when they had lost their citizenship, and empowered the Minister to act on information from security agencies without a full security assessment being conducted.

In September 2015, the PJCIS recommended 27 major changes to the Bill, aimed at 'making the Bill's scope more limited and procedures more transparent'. ${ }^{166}$ Subject to these changes, the PJCIS recommended that the legislation be passed. In November 2015, the government reintroduced an amended Bill into Parliament, adopting all of the PJCIS recommendations. This Bill was passed by both Houses of Parliament in December 2015.

The changes to Australian citizenship law imposed through the Allegiance to Australia Act retain the three avenues of citizenship deprivation outlined in the original Bill. However, the enacted model is tighter in scope. First, a dual citizen can lose citizenship by committing prescribed conduct, with the intention of advancing a political, religious or ideological cause; coercing or influencing a government by intimidation; or intimidating the public. ${ }^{167}$ The conduct that triggers citizenship loss is defined by reference to terrorism and foreign incursions and recruitment offences. ${ }^{168}$

Secondly, the long-standing provision providing for automatic citizenship loss for dual citizens who serve in the armed forces of a country at war with Australia is updated to include fighting for, or in the service of, a declared terrorist organization. ${ }^{169}$ However, the law specifies that being in the service of such an organization does not include the provision of 'neutral and independent humanitarian assistance', unintentional actions, or actions committed under duress or force. ${ }^{170}$ These two grounds are triggered automatically when a citizen engages in particular activity, and do not require a conviction.

Thirdly, a dual citizen can lose their citizenship if they are convicted of a prescribed offence. ${ }^{171}$ Unlike in the original Bill, this does not occur automatically - rather, the Minister has a discretion to revoke citizenship where he or she is satisfied that this would be in the public interest and that

165 See eg B Saul, Submission to Parliamentary Joint Committee on Intelligence and Security, Inquiry into the Australian Citizenship Amendment (Allegiance to Australia) Bill 2015, 5-8; Law Council of Australia, Submission to Parliamentary Joint Committee on Intelligence and Security, Inquiry into the Australian Citizenship Amendment (Allegiance to Australia) Bill 2015, 16-26; R Thwaites, Submission to Parliamentary Joint Committee on Intelligence and Security, Inquiry into the Australian Citizenship Amendment (Allegiance to Australia) Bill 2015, 5-7; all accessible at $<$ http://www.aph.gov.au/Parliamentary_Business/Committees/Joint/Intelligence_and_Security/ Citizenship_Bill/Submissions> .

166 See Commonwealth of Australia, Parliamentary Joint Committee on Intelligence and Security, 'Advisory Report on the Australian Citizenship Amendment (Allegiance to Australia) Bill 2015 (4 September 2015) <http://www.aph.gov.au/Parliamentary_Business/Committees/ Joint/Intelligence_and_Security/Citizenship_Bill/Report $>$.

167 Australian Citizenship Act 2007 (Cth), section 33AA(3).

168 ibid section 33AA(6). ${ }^{169}$ ibid section 35. ${ }^{170}$ ibid section 35(4). ${ }^{171}$ ibid section 35A. 
the conviction demonstrates a repudiation of allegiance to Australia. ${ }^{172}$ The list of offences that open up the possibility of citizenship loss has been refashioned. The prescribed offences now have a closer nexus with allegiance, and relate to terrorism, treason, treachery, sabotage, espionage and foreign incursions and recruitment. The possibility of citizenship revocation also only arises for citizens who have been sentenced to at least six years' imprisonment. ${ }^{173}$

The offences that trigger a ministerial discretion to revoke citizenship upon conviction include the forms of conduct, such as acts of terrorism, that also give rise to automatic citizenship loss on the first ground. In this sense, there is an overlap between the 'conduct based' and 'offence based' grounds for citizenship loss. The legislation deals with this by altering the fault element for 'conduct based' citizenship loss, ${ }^{174}$ and specifying that it only applies in limited circumstances: where a person has committed the relevant conduct outside Australia, or where they have left Australia before they can be brought to trial. ${ }^{175}$ In all other cases, only the offence based grounds for citizenship loss apply.

The conviction-based ground for citizenship revocation goes further than the original proposal in one fundamental respect. It allows for a person to be stripped of their citizenship on the basis of a conviction recorded prior to the commencement of the legislation. However, this retrospective application of the law only applies in regard to convictions that have occurred no more than ten years before the legislation's entry into force, and a higher sentencing threshold of ten years applies. ${ }^{176}$

The Allegiance to Australia Act incorporates a number of safeguards that were absent in the original proposal. While the original Bill could not totally exclude the possibility of judicial review, which is guaranteed by section $75(\mathrm{v})$ of the Australian Constitution, any such potential was undermined by the fact that the Bill did not require a person to be informed when they had been deemed to have lost their citizenship. This is now remedied with a requirement that the Minister take reasonable steps to inform a person who has lost their citizenship of this fact, a basic description of the reasons for citizenship loss and their rights of review. ${ }^{177}$

Additionally, the law now requires information received from security agencies to meet the criteria for a full security assessment, before it can be relied on to revoke citizenship. ${ }^{178}$ It also restricts citizenship loss via the

\footnotetext{
172 ibid section 35A(1). ${ }^{173}$ ibid section 35A(1)(b). ${ }^{174}$ See ibid, sections 33AA(3), 33AA(6).

175 ibid section 33AA(7).

176 ibid Application provisions, 4 ('Application of section 35A').

177 ibid section 33AA(10), (11); section 35(5), (6); section 35A(5), (6); section 35B(1), (2).
} Notice is not required where the Minister has determined that providing it could 'prejudice the security, defence or international relations of Australia, or Australian law enforcement operations': sections 33AA(12), 35(7), 35A(7).

178 See Australian Security Intelligence Organisation Act 1979 (Cth), section 39. This provision was expressly excluded in the original Bill. 
automatic mechanisms to persons over the age of $14,{ }^{179}$ and no provision is made for the children of a person affected by the law to also have their citizenship revoked.

While these and other changes significantly narrow the scope of the law and increase safeguards, the Australian legislation remains one of the broadest ranging regimes of citizenship deprivation in the world. The automatic citizenship stripping provisions, in particular, go further than even the UK legislation, by imposing citizenship deprivation upon all dual citizens that meet the designated criteria, irrespective of the level of threat they pose. The Minister has the power to consider whether to exempt a citizen from such loss. ${ }^{180}$ However, there is no duty to exercise or consider exercising this power. ${ }^{181}$ The rules of natural justice do apply to a ministerial decision to make or deny an exemption determination. However, this may be of no utility, as natural justice does not apply to the threshold decision the Minister must make about whether to consider making such a determination in the first place. ${ }^{182}$

The inclusion of foreign incursion and recruitment offences in the conviction based grounds for citizenship loss is another exceptional element of the revised law. As a result, citizenship stripping will apply to people who have been convicted of nothing more than entering an area declared by the government to be a no-go zone. The person need not have harmed anyone, and indeed may have entered the area against the wishes of the government merely to visit friends or to conduct business. ${ }^{183}$

\section{Justifications}

Australia possesses a wide range of other national security legislation, having passed 66 federal anti-terror statutes since the September 11 bombings. ${ }^{184}$ As in the UK and Canada, a key justification for why the Allegiance to Australia Act was needed in addition to this broad package of security laws was that the Act would affirm important features of the State-citizen relationship.

Once again, it was emphasized that citizenship involves duties of allegiance, and that violation of these duties warrants exclusion from the citizenry. For instance, a purpose provision included in the Allegiance to Australia Act states:

179 Australian Citizenship Act 2007 (Cth), sections 33AA(1), 35(1).

180 ibid sections 33AA(14), 35(9).

181 ibid section 33AA(15), (16); section 35(10), (11). Where this power is exercised, prescribed criteria must be considered: ibid, sections 33AA(17), 35(12).

182 ibid sections 33(22), 35(17). $\quad{ }^{183}$ See Criminal Code Act 1995 (Cth), section 119.2.

184 By mid-2014 Parliament had enacted 61 pieces of anti-terrorism legislation: G Williams, 'The Legal Legacy of the War on Terror' (2013) 12 Macquarie Law Journal 3, 7. A further five antiterrorism statutes have been enacted since then. This is the largest number of anti-terror statutes passed by any democratic nation in the twenty-first century, and Australia's response to terrorism has been characterized as one of 'hyper-legislation': K Roach, The 9/11 Effect: Comparative Counter-Terrorism (Cambridge University Press, 2011) 309. 
This Act is enacted because the Parliament recognizes that Australian citizenship is a common bond, involving reciprocal rights and obligations, and that citizens may, through certain conduct incompatible with the shared values of the Australian community, demonstrate that they have severed that bond and repudiated their allegiance to Australia. ${ }^{185}$

As in the UK and Canada, justifications for the Allegiance to Australia Act have also sought to paint citizenship as a conditional status, rather than a secure one. For instance, in an interview, Immigration Minister Peter Dutton said that:

[Australian citizenship] confers a great advantage on people and if people are going to swear an allegiance to our country and then go beyond that to - and in opposition to the words that they've just spoken at their citizenship ceremony attempt to attack Australians, there's a consequence to pay for that. ${ }^{186}$

The strong rhetorical affirmation that citizenship is predicated on allegiance seeks to draw on common law principle to lend legitimacy to the Allegiance to Australia Act. However, the Act itself subverts all three dimensions of common law citizenship. It creates two tiers of citizenship, as the new denationalization provisions only apply to dual citizens. For those citizens that the Act does apply to, citizenship is transformed from a status that is as secure and enduring irrespective of a citizen's behaviour to one that is contingent upon particular behaviour.

As in the UK and to a lesser extent Canada, it cannot even be said that the Act makes retaining citizenship contingent upon ongoing allegiance, as not all of the grounds for citizenship loss seem to require a clear lack of allegiance to Australia. This was a much larger issue in the initial Bill, which imposed citizenship loss in a fairly wide range of circumstances, including on all people convicted of damaging Commonwealth property. The Act as ultimately passed ties citizenship loss much more closely to allegiancerelated conduct. Nonetheless, certain revocation grounds - such as conviction for entering an area declared a no-go zone-do not require any repudiation of allegiance. This erodes the common law idea that the State owes protection in exchange for allegiance.

\section{THEMES AND OBSERVATIONS}

Citizenship as a common law concept has a number of fundamental characteristics. It is a compact between an individual and the State, under which the citizen pledges allegiance, and the State offers protection. It is also a status that places all its bearers in an equal position, irrespective of how

\footnotetext{
185 Australian Citizenship Amendment (Allegiance to Australia) Act (Cth), section 4.

186 Australian Broadcasting Corporation, "Australian citizenship "very serious obligation" says Peter Dutton referring to national security laws' (7.30, 23 June 2015) <http://www.abc.net.au/7.30/ content/2015/s4260728.htm>.
} 
they acquired citizenship. Finally, it is a secure relationship, originally regarded as permanent in nature.

The recent revocation laws enacted in the UK, Canada and Australia represent a very significant retreat from these common law principles. These laws shift citizenship from a secure status to one which is conditional upon the citizen's behaviour. They also undermine the idea of equality between citizens: dual citizens (and, in the UK, naturalized citizens) remain more vulnerable to revocation than others. The effect is to fundamentally alter the nature of the compact between the State and its citizens.

This retreat from common law principle is not an entirely new phenomenon. As the discussion above illustrates, such principles were eroded in similar ways by citizenship revocation legislation that was actively used in the context of World Wars I and II. While each of the three countries revised its citizenship laws in the second half of the twentieth century, to substantially align with common law principles once again, the UK and Australia maintained the possibility of citizenship loss on disloyalty grounds throughout this period, even when deprivations were not being made in practice. The recent expansion and renewed use of disloyalty based deprivation might, therefore, be viewed as the most recent example of a broader tendency to tighten membership laws in times of emergency, in ways that do not always reflect common law principle.

Nonetheless, the recent resurgence of citizenship stripping laws is remarkable. In the UK, such laws had become 'moribund' following decades of disuse. In Australia, disloyalty based revocation laws had not operated since the introduction of citizenship legislation in 1949, and in Canada, such laws were removed from the statute books in 1977. In this context the reinvigoration of citizenship stripping was, in itself, noteworthy, and has been described by some commentators as a return of the mediaeval legal concepts of 'banishment' or 'exile'. ${ }^{187}$

In addition, the extreme breadth of the laws that have been passed, especially in regard to the conferral of power upon the executive, is striking. The laws permit the revocation of one of the most fundamental of rights in any democratic society in a broad and ill-defined range of circumstances. This is highlighted by the use of vague criteria such as 'conducive to the public good' in the UK. Such criteria can be often be applied without the person affected having the opportunity to put their case in court or otherwise having a right or to natural justice. Both the UK law, which confers broad executive revocation power even when statelessness would ensue, and the Australian

187 See eg Macklin, 'The Privilege to Have Rights' (n 38) generally; H Irving and R Thwaites, 'Banishment, Australian style', European University Institute Citizenship Blog <http://eudocitizenship.eu/commentaries/citizenship-blog/1476-banishment-australian-style>; Canadian Bar Association, 'The CBA urges the government to amend Bill C-24 to ensure fairer and more efficient legislation' (30 April 2015) < http://www.cba.org/News-Media/Press-Releases/2014/TheCBA-urges-the-government-to-amend-Bill-C-24-to>. 
law, which allows for citizenship loss in a way that bypasses the need for a ministerial decision push denationalization law into new territory.

The manner in which denationalization laws were expanded varied between the three countries. In the UK, revocation powers expanded progressively, and typically in reaction to national security incidents and heightened threat to the community, but did not see regular use until the election of the Cameron government. In Canada and Australia, the broadening of citizenship stripping laws took place far more suddenly, and the laws enacted were presented as updates required to enable citizenship law to deal with contemporary challenges, especially the threat posed by foreign fighters. All three countries, however, adopt similar models for citizenship stripping, characterized by wide executive discretion and limited judicial involvement. Despite the existing breadth of the laws, the UK is considering further expansions. ${ }^{188}$

Given that the revocation laws in the UK, Canada and Australia signify a substantial retreat from common law citizenship principles, it is interesting that in all three countries, justifications for these laws have drawn heavily on the common law, by asserting that citizenship is predicated upon allegiance, and that this connection needs to be maintained. The reliance on this justification suggests that the common law still exerts an enduring influence over the way in which citizenship is shaped in these countries.

However, in all three countries, such justifications have distorted the common law, selectively invoking the duty of allegiance alongside rhetoric that actively attacks the other principles that characterize citizenship at common law: reciprocity, security and equality. In all three countries, governments have expressed the idea that citizenship is not a 'right', but a 'privilege' that individuals who deviate from community norms do not deserve to hold. For instance, David Cameron described returning jihadists as 'enemies of the state'. ${ }^{189}$ Tony Abbott was even more blunt. In addition to calling on all migrants to embrace 'Team Australia', ${ }^{190}$ he said:

There's been the benefit of the doubt at our borders, the benefit of the doubt for residency, the benefit of the doubt for citizenship and the benefit of the doubt at Centrelink ...We are a free and fair nation. But that doesn't mean we should let bad people play us for mugs, and all too often they have. ${ }^{191}$

Such rhetoric is starkly at odds with the common law's conception of citizenship as enduring even where a citizen engaged in treasonous

\footnotetext{
188 See Great Britain, Home Office (n 79) 33.

189 See B Farmer and P Dominiczak, 'David Cameron: Returning jihadists are "enemies of the state" The Telegraph (17 November 2014).

190 See J Owens, “Don't migrate unless you want to join our team": Abbott meets Islamic community' The Australian (18 August 2014).

191 See L Mannix, “Bad people” treating us as mugs: Abbott's national security warning' The Sydney Morning Herald (15 February 2015). For extracts of similar statements expressed by Minister Jason Kenney in the Canadian context see eg S Bell, 'Canada revokes citizenship of Toronto 18 ringleader using new anti-terror law’ National Post (26 September 2015).
} 
conduct. ${ }^{192}$ It fundamentally reshapes the way in which we conceive of citizenship, shifting it from a secure status to one which is increasingly conditional. As Audrey Macklin has argued, '[c]itizenship emerges as an enhanced form of conditional permanent residence, revocable through the exercise of executive discretion'. ${ }^{193}$ The fact that this reconfiguration of citizenship only applies with respect to particular citizens - dual citizens and, in the UK, naturalized citizens - undermines the idea that citizenship is an equal status. The allowance, in each country, for denationalization in particular circumstances that do not require non-allegiance erodes the image of citizenship as a compact in which citizens' allegiance is met with State protection.

It may be that a case can be made for employing rhetoric to reshape the concept of citizenship in times of emergency. ${ }^{194}$ Certainly, similar practices were adopted in the context of World Wars I and II. However, the twentyfirst century brand of revocation laws gives rise to two unique uncertainties.

First, although the context in which the current laws have been enacted has some parallels to World Wars I and II in that it is a time of heightened security concern, there are also a number of critical distinctions. The UK, Canada and Australia are not presently facing the imminent risks of war, but rather are seeking to minimize future risks of terrorist attack from within the populace. This is a much more indeterminate security concern than world war, and is not a threat that is marked by a formal start and end date. Indeed, the socalled 'war on terror' that was initiated after the 11 September 2001 attacks has now lasted longer than World Wars I and II combined. Despite the Trudeau government's steps to wind back the Strengthening Canadian Citizenship Act, such factors make it far more likely that the recent shift away from common law citizenship principles will be enduring rather than temporal. ${ }^{195}$

Secondly, the recent laws depart from the common law citizenship principles that previously governed entitlement to citizenship without substituting other principles in their place. This creates great uncertainty as to the factors that should inform whether citizens should retain or lose their citizenship. While the rhetorical justifications supplied for the laws suggest that a citizen is entitled to retain their citizenship so long as they maintain their allegiance to the State, laws in all three countries allow citizenship deprivation in circumstances where no breach of allegiance obligations is required. The breadth of discretion afforded to the executive in each country with respect to

192 See eg Viscount Finlay's comments in Johnstone v Pedlar [1921] 2 AC 262, 274.

193 Macklin, 'The Privilege to Have Rights' (n 38) 29.

194 For an argument along these lines, see Joppke (n 10).

195 More broadly, commentators have observed that, in a number of jurisdictions, anti-terror laws originally introduced as an emergency response to national security threats have ended up becoming enduring fixtures: see eg G Williams, 'A Decade of Australian Anti-Terror Laws' (2011) 35 MULR 1136, 1137; Ramraj et al. (n 5); Roach, The 9/11 Effect (n 184). 
revocation decisions exacerbates uncertainties about when citizenship should remain secure. Denationalization grounds may, in the future, be expanded by statutory amendment, as the UK has already contemplated. Without a clear understanding of the principles that underpin citizenship, it is hard to foresee where the limits to any such expansion may lie. John McCallum touched on this in his second reading speech for Bill C-6:

...the rules might be clear today about for what crime we have citizenship revoked and for what crime do we not, but those laws can change over time. I remember the former prime minister in the election campaign speculating about additional crimes that might be added. Who knows? It might be terrorism one year, and something else - whatever catches the attention of the government of the daycould be added the next year. It is a slippery slope, and one does not know where on that slope one will end up. ${ }^{196}$

\section{CONCLUSION}

Citizenship is often regarded as the most fundamental of human rights. In determining a person's membership of a community, it affects a host of basic entitlements, including political rights. As a result, the concept has a strong rhetorical dimension in forging understandings of what it is to belong to a community, and in shaping a country's sense of its own identity.

At common law, citizenship is characterized by three fundamental principles. First, citizens and the State owe each other reciprocal duties of allegiance and protection. Secondly, the State-citizen relationship is secure and enduring. Finally, all citizens are regarded as equal in status. While citizenship in the UK, Canada and Australia is now a statutory concept, its legislative development has continued to be informed by these common law principles. The influence of the common law on citizenship legislation has not been constant. During and after World Wars I and II, all three countries enacted denaturalization laws that eroded the common law's three fundamental citizenship principles. However, in the latter half of the twentieth century, the alignment between statutory citizenship and common law principle was substantially restored.

The recent denationalization laws enacted in all three countries mark a new retreat from the common law. These laws significantly extend government power and alter the relationship between citizens and the State by rendering citizenship less secure and less equal. The citizens that these laws apply to are no longer able to expect that their membership of the community will be retained irrespective of their actions. Instead, legislative developments have increasingly cast their citizenship as a conditional privilege, rather than as an inalienable status.

196 Canada, House of Commons Debates, 9 March 2016, 1605 (John McCallum). 
Curiously, the common law notion that citizenship is tethered to allegiance has been invoked, in isolation from other common law principles, as justification for these developments. This suggests that the common law has enduring rhetorical power, which lends legitimacy to legislative action.

Despite this rhetorical recourse to common law allegiance obligations, the redefinition of citizenship in the recent laws is not underpinned by any clear principle. The laws do not clearly reflect the idea that citizenship is based on allegiance, and actively subvert other common law citizenship principles. This raises significant questions about how the State-citizen relationship in the UK, Canada and Australia will be conceptualized in the future. The justifications offered for the current laws do not suggest any clear answer to these questions.

The fact that the recent reinvigoration of revocation has emerged in response to the indeterminate threat of terrorism makes it likely that the current uncoupling of contemporary citizenship from common law principles will be more enduring than it was in the context of World Wars I and II. Indeed, it is unlikely that we have seen the end of legislative innovations to expand citizenship revocation on security grounds. While the Trudeau government has moved to wind back disloyalty based citizenship revocation in Canada, this appears to be an anomaly. In addition to the UK's plans to expand its revocation laws, several countries, in the common law world and beyond have recently announced proposals to introduce or broaden denationalization legislation. ${ }^{197}$ In the absence of any lessening of the national security threat, it is likely that this trend will continue. If it does, the result may be an ongoing alteration of what it means to be a citizen in many nations.

\footnotetext{
197 These countries include: Bangladesh, Belgium, Israel, the Netherlands and Russia. See eg CR Abrar, 'Citizenship Law 2016: Need for thorough scrutiny, drastic revision' New Age (10 June 2016); European Union Democracy Observatory on Citizenship, 'New citizenship deprivation rules in the wake of the Paris attacks' <http://eudo-citizenship.eu/news/citizenship-news/1527new-citizenship-deprivation-rules-in-the-wake-of-paris-attacks $>\mathrm{H}$ Keinon, 'Netenyahu: Israelis joining ISIS will lose citizenship', The Jerusalem Post (23 November 2015); Bill 34356 (R2064), Amendment of the Dutch Nationality Law in connection with the withdrawal of Dutch citizenship in the interest of national security'; Russian Legal Information Agency, 'Russian lawmakers propose stripping citizenship for terrorism' (4 December 2015) <http://www. rapsinews.com/legislation_news/20151204/275025186.html>.
} 